\title{
Bibliometric Analysis of Digital Accounting Research
}

Ardianto Ardianto. Airlangga University, Indonesia, ardianto@feb.unair.ac.id

Nadia Anridho. Airlangga University, Indonesia, nadia.anridho@feb.unair.ac.id

\begin{abstract}
In 2015, International Journal of Digital Accounting Research reached fifteen-year milestone. This study provides bibliometric analysis of the 93 articles which were published from 2001 to 2015. Content and citation analyses were conducted to review and analyze published articles. This study contributes to accounting information system literature by analyzing the methodology used, main accounting topical areas, the contribution of authors and institutions as well as the citation analysis of IJDAR publication. The results of this study show that IJDAR is suitable for wide audience such as academics, graduate students, practitioners and all others interested in digital accounting research.
\end{abstract}

Keywords: digital accounting research, bibliometric analysis, content analysis, citation analysis

\section{INTRODUCTION}

Accounting information systems (AIS) research is important to practice and education (Poston and Grabski, 2000). AIS research has existed for many years at the intersection of the accounting and management information systems (MIS) domains (Murthy and Wiggins, 1999; Poston and Grabski, 2000; Sutton, 2004; Sutton and Arnold 2002). The emergence of the AIS discipline arises primarily 
from the application of information and communication technology in the accounting and auditing environment (Ferguson and Seow, 2011). Furthermore, Murthy and Wiggins (1999) mentioned that two broad categories of AIS research are first, accounting issues examined that have a clear systems orientation and second, MIS issues examined that have an accounting orientation.

This study aims to provide a bibliometric analysis of articles published in the International Journal of Digital Accounting Research (IJDAR). The IJDAR is one of journals which focus on accounting information system field. It aims to contribute to advancing knowledge and understanding of both theory and practice in digital accounting, by promoting high quality applied and theoretical research (International Journal of Digital Accounting Research, 2017). To support the contribution of IJDAR to accounting theory and practice, it is important to understand the development of this journal in 15 years from 2001-2015.

This study conducted bibliometric analyses by conducting content and citation analyses on all articles published in IJDAR during the period of 2001-2015. Content analyses were used to analyze the categorization of the methodology and main accounting topical areas of the articles. Citations were used to evaluate the contribution of articles, journals, departments, universities, countries, and individuals (O'Leary, 2008). In other words, citations aim to see the impact of articles, journals, departments, universities, countries, and individuals on existing research. This study contributes to accounting information system literature by analyzing the methodology used, main accounting topical areas, the contribution of authors and institutions as well as the citation analysis of articles published in IJDAR in the period of 2001-2015. Therefore, the objective of this study is to review and analyze articles published in IJDAR in the period of 2001-2015.

This article is organized as follows. In the next section, review of the literature is discussed followed by methodology conducted in this study. Next, research results are presented and followed by conclusions and suggestions for future research.

\section{LITERATURE REVIEW}

Several articles that discussed and reviewed AIS research have been published (Ferguson and Seow, 2011; O’Leary, 2008; Poston and Grabski, 2000). In 2000, Poston and Grabski reported a comprehensive review and analysis of AIS research for 17 years from 1982 to 1998 . The aim of their review was to identify 
trends in the underlying theories and research methods used in AIS research. They concluded that first, AIS research was entering a 'more balanced phase of research progression'. They noted that while computer science continued to dominate in informing AIS research theory, there was significant growth in psychology-based AIS research. Second, while model building was still the dominant research method used to investigate AIS-related issues, the research design base had widened.

In 2008, O’Leary reported the relationship between citations and appearances on "top 25" download lists in the International Journal of Accounting Information Systems. The results show that first, the number of citations and the number of times that a paper is in a "top 25" of downloaded papers are significantly correlated and second, the set of "top 25" downloaded papers has a disproportionate number of citations. Furthermore, in 2011, Ferguson and Seow reported an analysis of AIS articles published in 18 leading accounting, management information systems, and computer science journals from 1999 to 2009. They attempted to identify whether or not the focus of AIS research has changed, and if so how it has changed, since the Poston and Grabski (2000)'s article. The results show that first, AIS-related research has the continuing decline in analytical and model building research. The decline is associated with a similar decline in the use of computer science theory to motivate the research. Second, there are two theoretical platforms which are cognitive psychology and economics account for $48 \%$ of all AIS research. Third, experimental research methods and archival studies continue to grow as the preferred methods of testing the AISrelated theories.

Lastly, Muehlmann et al. (2015) conducted comprehensive analysis of the journal of emerging technologies in accounting for decade. They analyzed, first, the characteristics of the articles comprises the research methodologies and accounting areas as used in the Brigham Young University Accounting Research Rankings, novel classifications based on an expansion of the Brown and Vasarhelyi (1994) accounting research taxonomy, and the AACSB A7 data terms, artificial intelligence, contributing authors, and institutions. Second, the citation analysis reports a comparison of scholarly and patent results. 


\section{RESEARCH METHODOLOGY}

Content and citation analyses were conducted to examine the research characteristics of IJDAR articles as well as its influence on other articles. All articles published in the IJDAR from 2001 until 2015 were downloaded from IJDAR website. A total of 93 articles were reviewed. Of the 93 articles, 34 articles were published in the first quinquennium, 30 articles were published in the second quinquennium, and 29 articles were published in the third quinquennium. Table 1 shows the yearly publication count.

\begin{tabular}{c|c}
\hline Year & Number of Publication \\
\hline 2001 & 8 \\
2002 & 8 \\
2003 & 6 \\
2004 & 6 \\
2005 & 6 \\
First Quinquennium & $\mathbf{3 4}$ \\
\hline 2006 & 6 \\
2007 & 6 \\
2008 & 5 \\
2009 & 7 \\
2010 & 6 \\
Second Quinquennium & $\mathbf{3 0}$ \\
\hline 2011 & 6 \\
2012 & 6 \\
2013 & 5 \\
2014 & 6 \\
2015 & 6 \\
Third Quinquennium & $\mathbf{2 9}$ \\
\hline Total & $\mathbf{9 3}$ \\
\hline
\end{tabular}

Table 1. The Number of IJDAR Articles

\subsection{Content Analysis}

All downloaded articles were manually reviewed and classified. This study follow the classification scheme by Coyne et al. (2010) to categorize the methodology and main accounting topical areas of the articles. The classification of methodology consists of analytical, archival, experimental, and other. Furthermore, the classification of main accounting topical areas consists of accounting information system (AIS), auditing, financial, managerial, tax, and other. Furthermore, this study also analyzed authors and institutions which have high contributions to IJDAR. Following Muehlmann et al. (2015), the author contribution was weighted equally as 1.00 for each paper. When more than one authors contribute to one article, each author is weighted proportionally with the 
total value of 1.00 each paper. The same technique was used to count institution contribution.

\subsection{Citation Analysis}

The citation numbers for IJDAR articles were collected from Google Scholar and Scopus. All articles were downloaded and each article's citation number was retrieved from Google Scholar and Scopus citation database. Google Scholar was chosen because it provides a wide range of citation such as journals, conference proceedings, and books and it also provides a long period of time citation numbers. Scopus was chosen because IJDAR has been indexed in Scopus database since 2010, therefore, the citation number from Scopus database can only be counted from 2010. Furthermore, Harzing's Publish or Perish tool was used to cross-check the citation numbers. It provides rankings for article citations as well as generates an $\mathrm{H}$-index. In addition, average citation number was also counted. To count the average citation number, the citation number of 2001 divided by 15, the citation number of 2002 divided by 14, the citation number of 2001 divided by 13, and so on until the year of 2015 .

\section{PROPOSED AUDIT COGNITIVE ASSISTANT FRAMEWORK}

\subsection{Methodology Classification}

Table 2 shows methodology classification from articles published in IJDAR. Following Coyne et al. (2010), this study classified methodology into 4 categories such as analytical, archival, experimental, and other. For other methodology, based on analysis results and following classification from Muehlmann et al. (2015), it classified again into 7 categories such as bibliometric, case study, descriptive, design science, review, survey, and mixed study.

From the results, it can be seen that the top-three methodology used by the IJDAR articles were survey (25.9\%), archival (20.43\%), and design science (15.05\%). It followed by analytical (9.6\%), case study (8.6\%), review (7.53\%), experimental and descriptive (each of it 4.6\%), mixed (3.22\%), and bibliometric (1.07\%). Furthermore, second quinquennium was the most diverse time period. All methodologies were used by articles published during the year of 2006-2010. 


\begin{tabular}{l|ccccc}
\hline Analytical & 5 & 3 & 1 & 9 & 9.6 \\
Archival & 6 & 4 & 9 & 19 & 20.43 \\
Experimental & 0 & 3 & 1 & 4 & 4.3 \\
Other-Bibliometric & 0 & 1 & 0 & 1 & 1.07 \\
Other-Case Study & 4 & 2 & 2 & 8 & 8.6 \\
Other-Descriptive & 3 & 1 & 0 & 4 & 4.3 \\
Other-Design Science & 5 & 4 & 5 & 14 & 15.05 \\
Other-Review & 2 & 3 & 2 & 7 & 7.53 \\
Other-Survey & 8 & 8 & 8 & 24 & 25.9 \\
Other-Mixed & 1 & 1 & 1 & 3 & 3.22 \\
Total & $\mathbf{3 4}$ & $\mathbf{3 0}$ & $\mathbf{2 9}$ & $\mathbf{9 3}$ & $\mathbf{1 0 0}$
\end{tabular}

\subsection{Main Accounting Topical Areas Classification}

Table 3 shows main accounting topical areas classification from articles published in IJDAR. Following Coyne et al. (2010), this study classified topical areas into 6 categories such as accounting information system (AIS), auditing, financial, managerial, tax, and other. Based on analysis results, this study added 3 mixed areas which are combination between AIS and auditing, AIS and financial, and AIS and managerial.

From the results, it can be seen that the top-three topical areas discussed by the IJDAR articles were AIS (36.6\%), financial (24.73\%), and other (16.12\%). It followed by mixed AIS and financial (12.9\%), auditing and mixed AIS and auditing (each of it 3.22\%), and managerial, tax, and mixed AIS and managerial (each of it 1.07\%). Furthermore, second quinquennium was the most diverse time period. All methodologies were used by articles published during the year of 2006-2010. 


\begin{tabular}{|c|c|c|c|c|c|}
\hline & 2001-2005 & 2006-2010 & 2011-2015 & Total & $\%$ \\
\hline AIS & 8 & 15 & 11 & 34 & 36.6 \\
\hline Auditing & 1 & 2 & 0 & 3 & 3.22 \\
\hline Financial & 11 & 5 & 7 & 23 & 24.73 \\
\hline Managerial & 1 & 0 & 0 & 1 & 1.07 \\
\hline $\operatorname{Tax}$ & 0 & 0 & 1 & 1 & 1.07 \\
\hline Mixed-AIS and Auditing & 1 & 0 & 2 & 3 & 3.22 \\
\hline $\begin{array}{l}\text { Mixed-AIS and } \\
\text { Financial }\end{array}$ & 6 & 1 & 5 & 12 & 12.9 \\
\hline $\begin{array}{l}\text { Mixed-AIS and } \\
\text { Managerial }\end{array}$ & 1 & 0 & 0 & 1 & 1.07 \\
\hline Other & 5 & 7 & 3 & 15 & 16.12 \\
\hline Total & 34 & 30 & 29 & 93 & 100 \\
\hline
\end{tabular}

\subsection{Author Contribution}

From 2001-2015 articles published in IJDAR, 188 different authors have contributed. Those -authors come from different countries such as the U.S.A., Spain, Italy, Australia, the U.K., Belgium, Taiwan, Canada, Brazil, Egypt, Finland, Portugal, Saudi Arabia, Malaysia, Germany, India, Singapore, Slovakia, Ireland, Romania, Sweden, Tunisia, Norway, Mexico, and New Zealand. The top 19 authors which have contribution equal to 1 or more weight are shown in Table 4 in descending order.

As shown in Table 4, author with the most frequent is Ahmad A. Abu-Musa, whose weighted contribution count equal to 3. There are three authors with weighted contributioun counts equal to 2 or above- Michael Alles, Miklos A. Vasarhelyi, and Kinsun Tam. Furthermore, there are four authors with weighted contributioun counts more than 1- Enrique Bonsón, Javier De Andrés, Chih-Fong Tsai, and Nadine Lybaert. 


Author Name
Ahmad A. Abu-Musa
Michael Alles
Miklos A. Vasarhelyi
Kinsun Tam
Enrique Bonsón
Javier De Andrés
Chih-Fong Tsai
Nadine Lybaert

Count

3

2.333

2.083

2.053

1.833

1.583

1.333

1.333

Table 4. Author Contribution

\subsection{University Contribution}

From 2001-2015 articles published in IJDAR, 101 different universities and 13 different companies have contributed. The top 18 universities which weighted contribution count more than 1.00 are shown in Table 5 in descending order. As shown in Table 5, top-nine universities which weighted contribution count equal to 2 or above are Rutgers University, University at Albany, SUNY, Universidad Pablo de Olavide, Universidad de Huelva, University of Oviedo, Federal University of Santa Catarina, King Fahd University of Petroleum and Minerals, Universidad Complutense de Madrid, and Universidad de Salamanca.

\begin{tabular}{l|cc}
\multicolumn{1}{c}{ Institutions } & Country & Count \\
\hline Rutgers University & USA & 6 \\
University at Albany, SUNY & USA & 3.583 \\
Universidad Pablo de Olavide & Spain & 3.5 \\
Universidad de Huelva & Spain & 3 \\
University of Oviedo & Spain & 3 \\
Federal University of Santa Catarina & Brazil & 2 \\
King Fahd University of Petroleum and Minerals & Saudi Arabia & 2 \\
Universidad Complutense de Madrid & Spain & 2 \\
Universidad de Salamanca & Spain \\
Queensland University of Technology & Australia & 2 \\
University of Cádiz & Spain & 1.833 \\
University of Granada & Spain & 1.5 \\
University of Valencia & Spain & 1.5 \\
The University of Melbourne & Australia \\
National Chung Cheng University & Taiwan & 1.5 \\
University of Birmingham & UK & 1.3 \\
Bryant College & USA & 1.333 \\
Suffolk University & USA & 1.25
\end{tabular}

Table 5. Institution Contribution 


\subsection{The Most-Cited Articles}

Table 6 shows yearly number of citation. In total, from the period of 2001-2015, from Google Scholar database, IJDAR has 2,320 citations with the highest citation in 2002 with the total of 419 citations followed by 2011 with the total of 270 citations, and 2009 with the total of 250 citations. Based on average citation count, 2011 has the highest average number of 54, followed by 2009 with the average of 35.71, and 2010 with the average of 32.17. Furthermore, from Scopus database, IJDAR has 248 citations with the highest citation in 2011 with the total of 90 citations followed by 2010 with the total of 75 citations, and 2012 with the total of 40 citations. Based on average citation count, 2011 has the highest average number of 18, followed by 2010 with the average of 12.5, and 2012 with the average of 10 .

\begin{tabular}{|c|c|c|c|c|}
\hline Year & $\begin{array}{c}\text { Google Scholar } \\
\text { Citations }\end{array}$ & $\begin{array}{c}\text { Google Scholar } \\
\text { Average Citations }\end{array}$ & $\begin{array}{c}\text { Scopus } \\
\text { Citations }\end{array}$ & $\begin{array}{c}\text { Scopus Average } \\
\text { Citations }\end{array}$ \\
\hline 2001 & 258 & 17.20 & - & - \\
\hline 2002 & 419 & 29.93 & - & - \\
\hline 2003 & 222 & 17.08 & - & - \\
\hline 2004 & 63 & 5.25 & - & - \\
\hline 2005 & 171 & 15.54 & - & - \\
\hline First & 1,133 & - & - & - \\
\hline Quinquennium & & & & \\
\hline 2006 & 90 & 9 & - & - \\
\hline 2007 & 52 & 5.78 & - & - \\
\hline 2008 & 99 & 12.38 & - & - \\
\hline 2009 & 250 & 35.71 & - & - \\
\hline 2010 & 193 & 32.17 & 75 & 12.5 \\
\hline $\begin{array}{c}\text { Second } \\
\text { Quinquennium }\end{array}$ & 684 & - & 75 & - \\
\hline 2011 & 270 & 54 & 90 & 18 \\
\hline 2012 & 116 & 29 & 40 & 10 \\
\hline 2013 & 71 & 23.67 & 29 & 9.67 \\
\hline 2014 & 24 & 12 & 7 & 3.5 \\
\hline 2015 & 22 & 22 & 7 & 7 \\
\hline $\begin{array}{c}\text { Third } \\
\text { Quinquennium }\end{array}$ & 503 & - & 173 & - \\
\hline Total & 2,320 & - & 248 & - \\
\hline
\end{tabular}

Table 6. Yearly Number of Citation

Table 7 and Table 8 exhibit the results from Google Scholar database. Table 7 shows 10 most-cited articles from IJDAR. The highest citation number for article published in IJDAR is 182 from the article "The Use of the Internet for Corporate Reporting by Spanish Companies” written by Larran and Giner in 2002. From 11 
articles, 5 articles were discussed about financial reporting. It means that the "hot" topic for IJDAR is financial reporting that related with the use of technology. Table 8 shows top ten average citation number of articles published in IJDAR. From 11 articles in Table 7, only 7 articles were also included in top ten highest average cited article. It shows that there is a diferrence in the ranking when it is counted by citation number and average citation number. Article entitled "The impact of Accounting Information Systems (AIS) on performance measures: empirical evidence in Spanish SMEs” which published in 2011 written by Grande, Estebanez, and Colomina has the highest average citation number of 21.4.

\begin{tabular}{|c|c|c|c|c|}
\hline YEAR & AUTHOR & TITLE & CITATION & $\begin{array}{c}\text { AV } \\
\text { RANK }\end{array}$ \\
\hline 2002 & $\begin{array}{l}\text { Manuel Larran } \\
\text { and Begoña } \\
\text { Giner }\end{array}$ & $\begin{array}{l}\text { The Use of the Internet for } \\
\text { Corporate Reporting by } \\
\text { Spanish Companies }\end{array}$ & 182 & $\# 4$ \\
\hline 2003 & $\begin{array}{l}\text { Amir Allam and } \\
\text { Andrew Lymer }\end{array}$ & $\begin{array}{l}\text { Developments in Internet } \\
\text { Financial Reporting: } \\
\text { Review and Analysis, } \\
\text { Across Five Developed } \\
\text { Countries }\end{array}$ & 176 & \#3 \\
\hline 2002 & $\begin{array}{l}\text { Enrique Bonson } \\
\text { and Tomas } \\
\text { Escobar }\end{array}$ & $\begin{array}{l}\text { A Survey on Voluntary } \\
\text { Disclosure on the Internet. } \\
\text { Empirical Evidence from } \\
300 \text { European Union } \\
\text { Companies }\end{array}$ & 155 & $\# 5$ \\
\hline 2011 & $\begin{array}{l}\text { Elena Urquia } \\
\text { Grande, Raquel } \\
\text { Perez Estebanez, } \\
\text { Clara Munoz } \\
\text { Colomina }\end{array}$ & $\begin{array}{l}\text { The impact of Accounting } \\
\text { Information Systems (AIS) } \\
\text { on performance measures: } \\
\text { empirical evidence in } \\
\text { Spanish SMEs }\end{array}$ & 107 & $\# 1$ \\
\hline 2001 & $\begin{array}{l}\text { Roger } \\
\text { Debreceny. Glen } \\
\text { L. Gray and } \\
\text { Theodore J. } \\
\text { Mock }\end{array}$ & $\begin{array}{l}\text { Financial Reporting } \\
\text { Websites: What Users } \\
\text { Want in Terms of Form and } \\
\text { Content }\end{array}$ & 75 & - \\
\hline 2002 & Nadine Lybaert & $\begin{array}{l}\text { On-Line Financial } \\
\text { Reporting-An Analysis of } \\
\text { the Dutch Listed Firms }\end{array}$ & 72 & - \\
\hline 2011 & $\begin{array}{l}\text { Amelia A. } \\
\text { Baldwin, Brad S. } \\
\text { Trinkle }\end{array}$ & $\begin{array}{l}\text { The Impact of XBRL: A } \\
\text { Delphi Investigation }\end{array}$ & 71 & \#2 \\
\hline 2010 & $\begin{array}{l}\text { Manuel Pedro } \\
\text { Rodriguez } \\
\text { Bolivar, Laura } \\
\text { Alcaide Munoz, } \\
\text { Antonio M. } \\
\text { Lopez }\end{array}$ & $\begin{array}{l}\text { Trends of e-Government } \\
\text { Research. } \\
\text { Contextualization and } \\
\text { Research Opportunities }\end{array}$ & 66 & \#6 \\
\hline
\end{tabular}




20 \begin{tabular}{lll}
\hline $\mathbf{2 0 0 1}$ & $\begin{array}{l}\text { Hernandez } \\
\text { Severin V. }\end{array}$ & Risks and Controls in the \\
Grabski, Stewart & $\begin{array}{l}\text { Implementation of ERP } \\
\text { A. Leech and }\end{array}$ & Systems \\
Bal Lu & & \\
Enrique Bonson, & A Delphi Investigation to \\
Virginia Cortijo, & Explain the Voluntary \\
Tomas Escobar & Adoption of XBRL \\
Syou-Ching Lai, & An Empirical Study of the \\
Cecilia Lin, & Impact of Internet Financial \\
Hung-Chih Li, & Reporting on Stock Prices \\
Frederick H. Wu & Table 7. Top Ten Most-Cited Articles by Google Scholar
\end{tabular}

\begin{tabular}{|c|c|c|c|c|}
\hline YEAR & AUTHOR & TITLE & CITATION & AVERAGE \\
\hline 2011 & $\begin{array}{l}\text { Elena Urquia } \\
\text { Grande, Raquel } \\
\text { Perez Estebanez, } \\
\text { Clara Munoz } \\
\text { Colomina }\end{array}$ & $\begin{array}{l}\text { The impact of Accounting } \\
\text { Information Systems (AIS) on } \\
\text { performance measures: } \\
\text { empirical evidence in Spanish } \\
\text { SMEs }\end{array}$ & 107 & 21.4 \\
\hline 2011 & $\begin{array}{l}\text { Amelia A. } \\
\text { Baldwin, Brad S. } \\
\text { Trinkle }\end{array}$ & $\begin{array}{l}\text { The Impact of XBRL: A Delphi } \\
\text { Investigation }\end{array}$ & 71 & 14.2 \\
\hline 2003 & $\begin{array}{l}\text { Amir Allam and } \\
\text { Andrew Lymer }\end{array}$ & $\begin{array}{l}\text { Developments in Internet } \\
\text { Financial Reporting: Review } \\
\text { and Analysis, Across Five } \\
\text { Developed Countries }\end{array}$ & 176 & 13.58 \\
\hline 2002 & $\begin{array}{l}\text { Manuel Larran } \\
\text { and Begoña Giner }\end{array}$ & $\begin{array}{l}\text { The Use of the Internet for } \\
\text { Corporate Reporting by Spanish } \\
\text { Companies }\end{array}$ & 182 & 13 \\
\hline 2002 & $\begin{array}{l}\text { Enrique Bonson } \\
\text { and Tomas } \\
\text { Escobar }\end{array}$ & $\begin{array}{l}\text { A Survey on Voluntary } \\
\text { Disclosure on the Internet. } \\
\text { Empirical Evidence from } 300 \\
\text { European Union Companies }\end{array}$ & 155 & 11.07 \\
\hline 2010 & $\begin{array}{l}\text { Manuel Pedro } \\
\text { Rodriguez } \\
\text { Bolivar, Laura } \\
\text { Alcaide Munoz, } \\
\text { Antonio M. Lopez } \\
\text { Hernandez }\end{array}$ & $\begin{array}{l}\text { Trends of e-Government } \\
\text { Research. Contextualization and } \\
\text { Research Opportunities }\end{array}$ & 66 & 11 \\
\hline 2013 & $\begin{array}{l}\text { Hazar Daoud, } \\
\text { Mohamed Triki }\end{array}$ & $\begin{array}{l}\text { Accounting Information } \\
\text { Systems in an ERP } \\
\text { Environment and Tunisian Firm } \\
\text { Performance }\end{array}$ & 31 & 10.33 \\
\hline 2011 & $\begin{array}{l}\text { Sutapat } \\
\text { Thiprungsri, } \\
\text { Miklos A. } \\
\text { Vasarhelyi }\end{array}$ & $\begin{array}{l}\text { Cluster Analysis for Anomaly } \\
\text { Detection in Accounting Data: } \\
\text { An Audit Approach }\end{array}$ & 50 & 10 \\
\hline 2012 & Jamshed J. & An Empirical Analysis of the & 39 & 9.75 \\
\hline
\end{tabular}




$2010 \mid \begin{aligned} & \text { Mistry, Abu Jalal } \\ & \text { Syou-Ching Lai, } \\ & \text { Cecilia Lin, } \\ & \text { Hung-Chih Li, } \\ & \text { Frederick H. Wu }\end{aligned}$

Relationship between egovernment and Corruption An Empirical Study of the Impact of Internet Financial Reporting on Stock Prices

53 8.83

Table 8. Top Ten Highest-Average-Cited Articles by Google Scholar

Table 9 and Table 10 exhibit the results from Scopus database. Table 9 shows 10 most-cited articles from IJDAR. The highest citation number for article published in IJDAR is 37 from the article "Trends of e-Government Research. Contextualization and Research Opportunities” written by Bolivar, Munoz, and Hernandez in 2010. Different from Google Scholar results, the "hot" topic for IJDAR is XBRL and followed by e-government. It is shown by from 15 articles, 5 articles were discussed about XBRL and 3 articles were discussed about egovernment. Table 10 shows top ten average citation number of articles published in IJDAR. From 15 articles in Table 9, 12 articles were also included in top ten highest average cited article. It shows that there is no big diferrence in the ranking when it is counted by citation number and average citation number. Article entitled "The Impact of XBRL: A Delphi Investigation" which published in 2011 written by Baldwin and Trinkle has the highest average citation number of 7.2.

\section{YEAR AUTHOR}

2010

Manuel Pedro

Rodriguez Bolivar,

Laura Alcaide

Munoz, Antonio

M. Lopez

Hernandez

2011 Amelia A.

Baldwin, Brad S.

Trinkle

2011

Sutapat

Thiprungsri,

Miklos A.

Vasarhelyi

2012

2011

Jamshed J. Mistry, Abu Jalal

Elena Urquia

\section{TITLE}

Trends of e-Government Research.

Contextualization and Research

Opportunities Grande, Raquel Perez Estebanez,
The Impact of XBRL: A Delphi

Investigation

Cluster Analysis for Anomaly

Detection in Accounting Data: An

Audit Approach

An Empirical Analysis of the

Relationship between e-government and Corruption

The impact of Accounting Information Systems (AIS) on performance measures: empirical evidence in
16

CITATION AV

37

RANK

\#2

36

\#1

22

\#3

\#4

15

\#5 


\begin{tabular}{|c|c|c|c|c|}
\hline & $\begin{array}{l}\text { Clara Munoz } \\
\text { Colomina }\end{array}$ & Spanish SMEs & & \\
\hline 2010 & $\begin{array}{l}\text { Saeed Roohani, } \\
\text { Zhao Xianming, } \\
\text { Ernest A. } \\
\text { Capozzoli, } \\
\text { Barbara } \\
\text { Lamberton }\end{array}$ & $\begin{array}{l}\text { Analysis of XBRL Literature: A } \\
\text { Decade of Progress and Puzzle }\end{array}$ & 13 & \#8 \\
\hline 2011 & $\begin{array}{l}\text { Diego Valentinetti, } \\
\text { Michele A. Rea }\end{array}$ & $\begin{array}{l}\text { Adopting XBRL in Italy: Early } \\
\text { evidence of fit between Italian GAAP } \\
\text { Taxonomy and current reporting } \\
\text { practices of non-listed companies }\end{array}$ & 10 & \#7 \\
\hline 2012 & $\begin{array}{l}\text { Oana Velcu- } \\
\text { Laitinen, Ogan M. } \\
\text { Yigitbasioglu }\end{array}$ & $\begin{array}{l}\text { The Use of Dashboards in Performance } \\
\text { Management: Evidence from Sales } \\
\text { Managers }\end{array}$ & 10 & $\# 8$ \\
\hline 2013 & $\begin{array}{l}\text { Ogan M. } \\
\text { Yigitbasioglu, } \\
\text { Kim Mackenzie, } \\
\text { Rouhshi Low }\end{array}$ & $\begin{array}{l}\text { Cloud Computing: How does it differ } \\
\text { from IT outsourcing and what are the } \\
\text { implications for practice and research? }\end{array}$ & 9 & \#5 \\
\hline 2012 & $\begin{array}{l}\text { Srinivasan (Srini) } \\
\text { Ragothaman }\end{array}$ & $\begin{array}{l}\text { Voluntary XBRL Adopters and Firm } \\
\text { Characteristics: An Empirical Analysis }\end{array}$ & 8 & \#8 \\
\hline 2013 & $\begin{array}{l}\text { Hazar Daoud, } \\
\text { Mohamed Triki }\end{array}$ & $\begin{array}{l}\text { Accounting Information Systems in an } \\
\text { ERP Environment and Tunisian Firm } \\
\text { Performance }\end{array}$ & 8 & \#6 \\
\hline 2010 & $\begin{array}{l}\text { Syou-Ching Lai, } \\
\text { Cecilia Lin, Hung- } \\
\text { Chih Li, Frederick } \\
\text { H. Wu }\end{array}$ & $\begin{array}{l}\text { An Empirical Study of the Impact of } \\
\text { Internet Financial Reporting on Stock } \\
\text { Prices }\end{array}$ & 7 & - \\
\hline 2010 & $\begin{array}{l}\text { Carmen de Pablos } \\
\text { Heredero, David } \\
\text { Lopez Berzosa, } \\
\text { Roberto Santos } \\
\text { Santos }\end{array}$ & $\begin{array}{l}\text { The Implementation of Free Software } \\
\text { in Firms: An Empirical Analysis }\end{array}$ & 7 & - \\
\hline 2010 & $\begin{array}{l}\text { Byron Marshall, } \\
\text { Kristian } \\
\text { Mortenson, Amy } \\
\text { Bourne, Kevin } \\
\text { Price }\end{array}$ & $\begin{array}{l}\text { Visualizing Basic Accounting Flows: } \\
\text { Does XBRL + Model + Animation = } \\
\text { Understanding? }\end{array}$ & 7 & - \\
\hline 2011 & $\begin{array}{l}\text { Luis Rodriguez- } \\
\text { Dominguez, Isabel } \\
\text { Maria Garcia } \\
\text { Sanchez, Isabel } \\
\text { Gallego Alvarez }\end{array}$ & $\begin{array}{l}\text { From Emerging to Connected E- } \\
\text { Government: The Effects of } \\
\text { Socioeconomics and Internal } \\
\text { Administration Characteristics }\end{array}$ & 7 & $\# 10$ \\
\hline
\end{tabular}

Table 9. Top Ten Most-Cited Articles by Scopus

\begin{tabular}{r|llcc} 
YEAR & AUTHOR & TITLE & CITATION & AVERAGE \\
\hline $\mathbf{2 0 1 1}$ & $\begin{array}{l}\text { Amelia A. } \\
\text { Baldwin, Brad S. } \\
\text { Trinkle }\end{array}$ & $\begin{array}{l}\text { The Impact of XBRL: A } \\
\text { Delphi Investigation }\end{array}$ & 36 & 7.2 \\
$\mathbf{2 0 1 0}$ & Manuel Pedro & Trends of e-Government & 37 & 6.17
\end{tabular}


Rodriguez Bolivar, Research. Contextualization

Laura Alcaide and Research Opportunities

Munoz, Antonio

M. Lopez

Hernandez

2011

Sutapat

Thiprungsri, Miklos A.

Vasarhelyi

2012

2011

Jamshed J. Mistry,

Abu Jalal

Elena Urquia

Grande, Raquel

Perez Estebanez,

Clara Munoz

Colomina

2013

2015

2013

2010

2012

2012

2013
Saeed Roohani,

Zhao Xianming,

Ernest A.

Capozzoli, Barbara

Lamberton

Oana Velcu-

Laitinen, Ogan M.

Yigitbasioglu

Mackenzie,

Rouhshi Low

Hazar Daoud,

Mohamed Triki

Diego Valentinetti,

Michele A. Rea

Srinivasan (Srini)

Ragothaman

Siripan

Kuenkaikaew, Miklos A.
Cluster Analysis for

Anomaly Detection in

Accounting Data: An Audit

Approach

An Empirical Analysis of

the Relationship between e-

government and Corruption

The impact of Accounting

Information Systems (AIS)

on performance measures:

empirical evidence in

Spanish SMEs

Cloud Computing: How

16

4

15

3

does it differ from IT

outsourcing and what are the

implications for practice and

research?

Developing a new service

3

3

for the digital traveler

satisfaction: The Smart

Tourist App

Accounting Information

2.67

Systems in an ERP

Environment and Tunisian

Firm Performance

Adopting XBRL in Italy:

Early evidence of fit

between Italian GAAP

Taxonomy and current

reporting practices of non-

listed companies

Analysis of XBRL

13

2.17

Literature: A Decade of

Progress and Puzzle

The Use of Dashboards in

10

Performance Management:

Evidence from Sales

Managers

Voluntary XBRL Adopters

8

2

and Firm Characteristics: An

Empirical Analysis

The Predictive Audit

6

4.4

3

Framework 


\begin{tabular}{|c|c|c|c|c|}
\hline & Vasarhelyi & & & \\
\hline \multirow[t]{4}{*}{2014} & Ehab K. A. & Determinants and & \multirow[t]{4}{*}{4} & \multirow[t]{4}{*}{2} \\
\hline & Mohamed, & Characteristics of Voluntary & & \\
\hline & Mohamed A. K. & Internet Disclosures in GCC & & \\
\hline & Basuony & Countries & & \\
\hline \multirow[t]{6}{*}{2015} & Cassy Henderson, & Standardizing the & \multirow[t]{6}{*}{2} & \multirow[t]{6}{*}{2} \\
\hline & Esperanza Huerta, & Presentation of Financial & & \\
\hline & Terry Ann & Data: Does XBRL’s & & \\
\hline & Glandon & Taxonomy Affect the & & \\
\hline & & Investment Performance of & & \\
\hline & & Nonprofessional Investors? & & \\
\hline \multirow[t]{6}{*}{2011} & Luis Rodriguez- & From Emerging to & \multirow[t]{6}{*}{7} & \multirow[t]{6}{*}{1.4} \\
\hline & Dominguez, Isabel & Connected E-Government: & & \\
\hline & Maria Garcia & The Effects of & & \\
\hline & Sanchez, Isabel & Socioeconomics and Internal & & \\
\hline & Gallego Alvarez & Administration & & \\
\hline & 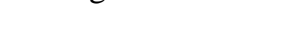 & Characteristics & & \\
\hline
\end{tabular}

Table 10. Ten Highest-Average-Cited Articles by Scopus

\section{CONCLUSIONS}

The objective of this study is to review and analyze articles published in IJDAR in the period of 2001-2015. This study contributes to accounting information system literature by analyzing the methodology used, main accounting topical areas, the contribution of authors and institutions as well as the citation analysis of IJDAR publication. Several conclusions can be concluded from this study. First, survey is the methodology that used the most by the authors. Second, accounting topical research area is dominated by accounting information system which is in line with the scope of IJDAR. The aim of IJDAR is to contribute to advancing knowledge and understanding of both theory and practice in digital accounting, by promoting high quality applied and theoretical research. Third, the authors and institutions which contribute to IJDAR are mainly from the USA, Spain, and Australia. The IJDAR provides quite diverse research articles. The results of this study show that IJDAR is suitable for wide audience such as academics, graduate students, practitioners and all others interested in digital accounting research since its contributors come from different background.

\section{Funding}

This work was supported by Faculty of Economics and Business, Universitas Airlangga research grants. 


\section{REFERENCES}

ALLAM, A.; LYMER, A. (2003): “Developments in internet financial reporting: Review and analysis- Across five developed countries", The International Journal of Digital Accounting Research: vol. 3, n. 6: 165-199. https://doi.org/ 10.4192/1577-8517-v3_6

BALDWIN, A. A.; TRINKLE, B. S. (2011): "The Impact of XBRL: A Delphi Investigation”, The International Journal of Digital Accounting Research: vol. 11: 1-24. https://doi.org/10.4192/1577-8517-v11_1

BOLIVAR, M. P. R.; MUNOZ, L. A.; HERNANDEZ, A. M. L. (2010): “Trends of e-government research. Contextualization and research opportunities”, The International Journal of Digital Accounting Research: vol. 10: 87-111. https://doi.org/10.4192/1577-8517-v10_4

BONSÓN, E.; CORTIJO, V.; ESCOBAR, T. (2009): “A delphi investigation to explain the voluntary adoption of XBRL”, The International Journal of Digital Accounting Research: vol. 9: 193-205. https://doi.org/10.4192/1577-8517-v9_7

BONSÓN, E.; ESCOBAR, T. (2002). “A survey on voluntary disclosure on the internet- Empirical evidence from 300 European Union Companies”, The International Journal of Digital Accounting Research: vol. 2, n. 1: 27-51. https://doi.org/10.4192/1577-8517-v2_2

BROWN, L. D.; VASARHELYI, M. A. (1994): Accounting Research Directory: The Database of Accounting Literature. Marcus Wiener Publishing, New York.

COYNE, J. G.; SUMMERS, S. L.; WILLIAMS, B.; WOOD, D. A. (2010): "Accounting program research rankings by topical area and methodology", Issues in Accounting Education: vol. 25, n. 4: 631-654. https://doi.org/10.2308/iace.2010.25.4.631

DAOUD, H.; TRIKI, M. (2013): “Accounting information systems in an ERP environment and Tunisian firm performance”, The International Journal of Digital Accounting Research: vol. 13: 1-35. https://doi.org/10.4192/1577-8517-v13_1

DEBRECENY, R.; GRAY, G. L.; MOCK, T. J. (2001): "Financial reporting websites- What users want in terms of form and content", The International Journal of Digital Accounting Research: vol. 1, n. 1: 1-23. https://doi.org/10.4192/1577-8517-v1_1 
FERGUSON, C.; SEOW, P. S. (2011): “Accounting information systems research over the past decade: Past and future trends”, Accounting and Finance, vol. 51, n. 1: 235-251. https://doi.org/10.1111/j.1467-629X.2010.00393.x

GRABSKI, S. V.; LEECH, S. W.; LU, B. (2001): "Risks and controls in the implementation of ERP systems", The International Journal of Digital Accounting Research, vol. 1, n. 1: 47-68. https://doi.org/10.4192/1577-8517-v1_3

GRANDE, E. U.; ESTEBANEZ, R. P.; COLOMINA, C. M. (2011): “The impact of Accounting Information Systems (AIS) on performance measures: Empirical evidence in Spanish SMEs”, The International Journal of Digital Accounting Research, vol. 11: 24-43. https://doi.org/10.4192/1577-8517-v11_2

HANDERSON, C.; HUERTA, E.; GLANDON, T. A. (2015): "Standardizing the presentation of financial data: Does XBRL's taxonomy affect the investment performance of nonprofessional investors?', The International Journal of Digital Accounting Research, vol. 15: 24-43. https://doi.org/10.4192/1577-8517-v15_5

HEREDERO, C. D.; BERZOSA, D. L.; SANTOS, R. S. (2010): "The implementation of free software in firms: An empirical analysis", The International Journal of Digital Accounting Research, vol. 10: 127-153. https://doi.org/10.4192/1577-8517-v10_5

INTERNATIONAL JOURNAL OF DIGITAL ACCOUNTING RESEARCH (2017): Aims and Scope. http://www.ijdar.org/aims-and-scope.

KUENKAIKAEW, S.; VASARHELYI, M. A. (2013): "The predictive audit framework”, The International Journal of Digital Accounting Research, vol. 13: 37-71. https://doi.org/10.4192/1577-8517-v13_2

LAI, S. C.; LIN, C.; LI, H. C.; WU, F. H. (2010): “An Empirical Study of the Impact of Internet Financial Reporting on Stock Prices”, The International Journal of Digital Accounting Research, vol. 10: 1-26. https://doi.org/10.4192/1577-8517v10_1

LARRAN, M.; GINER, B. (2002): “The use of the internet for corporate reporting by Spanish companies", The International Journal of Digital Accounting Research, vol. 2, n. 1: 53-82. https://doi.org/10.4192/1577-8517-v2_3

LYBAERT, N. (2002): "On-line financial reporting-An analysis of the Dutch listed firms”, The International Journal of Digital Accounting Research: vol. 2, n. 4: 195-234. https://doi.org/10.4192/1577-8517-v2_7 
MARSHALL, B.; MORTENSON, K.; BOURNE, A.; PRICE, K. (2010): "Visualizing basic accounting flows: Does XBRL + Model + Animation = Understanding?”, The International Journal of Digital Accounting Research: vol. 10: 27-54. https://doi.org/10.4192/1577-8517-v10_2

MISTRY, J. J.; JALAL, A. (2012): “An empirical analysis of the relationship between e-government and corruption”, The International Journal of Digital Accounting Research: vol. 12: 145-176. https://doi.org/10.4192/1577-8517-v12_6

MOHAMED, E. K. A.; BASUONY, M. A. K. (2014): "Determinants and characteristics of voluntary internet disclosures in GCC countries", The International Journal of Digital Accounting Research: vol. 14: 57-91. https://doi.org/10.4192/1577-8517-v14_3

MUEHLMANN, B. W.; CHIU, V.; LIU, Q. (2015): "Emerging technologies research in accounting: JETA's first decade”, Journal of Emerging Technologies in Accounting, vol. 12: 17-50. https://doi.org/10.2308/jeta-51245

MURTHY, U. S.; WIGGINS, JR., C. E. (1999): “A perspective on accounting information systems research”, Journal of Information Systems, vol. 13, n. 1: 3-6. https://doi.org/10.2308/jis.1999.13.1.3

O'LEARY, D. (2008): “On the relationship between citations and appearances on "top 25" download lists in the International Journal of Accounting Information Systems”, International Journal of Accounting Information Systems, vol. 9: 6175. https://doi.org/10.1016/j.accinf.2008.02.001

PALUMBO, F. (2015): "Developing a new service for the digital traveler satisfaction: The Smart Tourist App”, The International Journal of Digital Accounting Research: vol. 15: 33-67. https://doi.org/10.4192/1577-8517-v15_2

POSTON, R.; GRABSKI, S. (2000): “Accounting information systems research: is it another QWERTY?” International Journal of Accounting Information Systems, vol. 1, n. 1: 9-53. https://doi.org/10.1016/S1467-0895(99)00003-2

RAGOTHAMAN, S. (2012): "Voluntary XBRL adopters and firm characteristics: An empirical analysis”, The International Journal of Digital Accounting Research: vol. 12: 93-119. https://doi.org/10.4192/1577-8517-v12_4

RODRIGUEZ-DOMINGUEZ; L.; SANCHEZ, I. M. G.; ALVAREZ. I. G. (2011): "From Emerging to connected e-government: the effects of socioeconomics and internal administration characteristics”, The International 
Journal of Digital Accounting Research: vol. 11: 85-109. https://doi.org/10.4192/1577-8517-v11_5

ROOHANI, S.; XIANMING, E. A.; LAMBERTON, B. (2010): “Analysis of XBRL literature: A decade of progress and puzzle", The International Journal of Digital Accounting Research: vol. 10: 131-147. https://doi.org/10.4192/15778517-v10_6

SUTTON, S. (2004): "Editors comments: Rediscovering our IS roots", The International Journal of Accounting Information Systems, vol. 5: 1-4. https://doi.org/10.1016/j.accinf.2004.02.001

SUTTON, S.; ARNOLD, V. (2002): Foundations and frameworks for AIS research, in Researching Accounting as an Information Systems Discipline. Edited by V. Arnold and S. G. Sutton. Sarasota, America: American Accounting Association.

THIPRUNGSRI, S.; VASARHELYI, M. A. (2011): "Cluster analysis for anomaly detection in accounting data: An audit approach", The International Journal of Digital Accounting Research, vol. 11: 69-84. https://doi.org/10.4192/1577-8517v11_4

VALENTINETTI, D.; REA, M. A. (2011): “Adopting XBRL in Italy: Early evidence of fit between Italian GAAP Taxonomy and current reporting practices of non-listed companies”, The International Journal of Digital Accounting Research, vol. 11: 45-67. https://doi.org/10.4192/1577-8517-v11_3

VELCU-LAITINEN, O.; YIGITBASIOGLU, O. M. (2012): "The use of dashboards in performance management: Evidence from sales managers", The International Journal of Digital Accounting Research, vol. 12: 39-58. https://doi.org/10.4192/1577-8517-v12_2

WHITE, H. D.; GRIFFITH, B. C. (1981): "Author cocitation - A literature measure of intellectual structure", Journal of the American Society for Information Science, vol. 32, n. $\quad 3$ : 163-171. https://doi.org/10.1002/asi.4630320302

YIGITBASIOGLU, O. M.; MACKENZIE, K.; LOW, R. (2013): “Cloud computing: How does it differ from IT outsourcing and what are the implications for practice and research?”, The International Journal of Digital Accounting Research, vol. 13: 99-121. https://doi.org/10.4192/1577-8517-v13_4 